\title{
Acid sulfate soils - Its characteristics and nutrient dynamics
}

K. R. DHANYA AND R. GLADIS

Received : 25.03.2017; Accepted : 28.05.2017

MEMBERS OF RESEARCH FORUM:

Corresponding author :

K.R. DHANYA, Department of Soil Science and Agricultural Chemistry, College of Agriculture, Vellayani,

Trivandrum,

THIRUVANANTHAPURAM (KERALA)

INDIA

Email: dhanyamadurai@gmail.com

Co-authors :

R. GLADIS, Department of Soil Science and Agricultural Chemistry,

College of Agriculture, Vellayani,

Trivandrum,

THIRUVANANTHAPURAM (KERALA)

INDIA

\section{Summary}

Soil is a hetereogenous, dynamic, living system that supports life on earth. Soil health and soil quality are of great relevance in the present day agriculture due to the continuous degradation of soil. Soil acidity is an important parameter that affects the crop yield and quality. Among the acid soils, acid sulfate soils are of great importance because they occupy a considerable area and are potentially productive soils. The objective of this paper is to present a review about the constraints of acid sulfate soils like acidity parameters and nutrient dynamics that hampers crop production.

Key words : Acid sulfate, Pyrite, Sulfuric acid, Acidity, Aluminium, Iron

How to cite this article : Dhanya, K.R. and Gladis, R. (2017). Acid sulfate soils - Its characteristics and nutrient dynamics. Asian J. Soil Sci., 12 (1) : 221-227 : DOI : 10.15740/HAS/AJSS/12.1/221-227. 